IRA-International Journal of Education \& Multidisciplinary Studies

ISSN 2455-2526; Vol.04, Issue 01 (2016)

Institute of Research Advances

http://research-advances.org/index.php/IJEMS

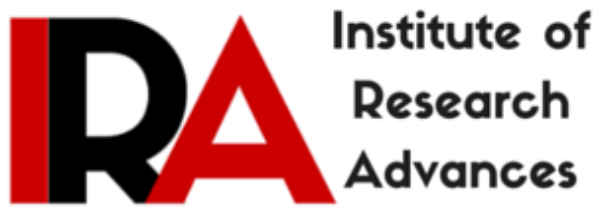

\title{
Bilateral Investment Treaty Negotiations between India and U.S: Problems and Prospects
}

Dr. Rajesh Kumar, Assistant Professor NUSRL, Ranchi, India.

DOI: $\underline{\text { http://dx.doi.org/10.21013/jems.v4.n1.p1 }}$

\section{How to cite this paper:}

Kumar, R. (2016). Bilateral Investment Treaty Negotiations between India and U.S: Problems and Prospects. IRA International Journal of Education and Multidisciplinary Studies (ISSN 2455-2526), 4(1). doi:http://dx.doi.org/10.21013/jems.v4.n1.p1

(C) Institute of Research Advances

\section{(oc) EY-NC}

This works is licensed under a Creative Commons Attribution-Non Commercial 4.0 International License subject to proper citation to the publication source of the work.

Disclaimer: The scholarly papers as reviewed and published by the Institute of Research Advances (IRA) are the views and opinions of their respective authors and are not the views or opinions of the IRA. The IRA disclaims of any harm or loss caused due to the published content to any party. 


\section{Background}

Relationship between U.S. and India is at the best phase, especially after former unequivocal support in NSG (Nuclear Supply Group) and helping inclusion in MTCR (Missile Technology Control Regime). The relationship between two oldest and biggest democracies has matured under the headship of Mr. Barak Obama as President and Mr. Nardendra Modi as prime minister. In the recent visit of Indian prime minister, the warm gesture shown by U.S. congress members have further cemented the strength of tie up between two nations. However, despite great chemistry between two nation and its leaders from last many years, both have failed to enter into Bilateral Investment Treaty. India is having Bilateral Investment treaty with more than 80 countries including U.K. and Russia, of which 72 treaties are operational. ${ }^{1}$ U.S. is having Bilateral Investment treaties with more than 46 countries including Russia and Bangladesh. ${ }^{2}$ Since 2008, the two countries have been engaged in sporadic discussions to conclude the Investment treaty. Negotiations on its wording, based on each country's revised model treaty texts, will begin soon. Both the leaders Indian Prime Minister Narendra Modi and U.S President Barack Obama affirmed their mutual commitment to facilitating increased bilateral investment flows and fostering an open and predictable climate for investment many a times, But consensus has not been reached till today on certain term and conditions. In the absence of BIT , the rights of investors of both the countries are at the stake. Further, MFN or nationality treatment clause cannot be invoked or granted in the event of any regulatory or other action. Obligations imposed by BIT to protect interest of foreign investors are absent. Further, after losing its first Investment Treaty Arbitration (ITA) claim in 2012 against White Industries, an Australian company and pending 17 cases, India has recently adopted new BIT in 2015 . It also has reflections of pending claims of Vodafone and other cases involving Intellectual Property Rights( Hereinafter refereed as IPR) and the cases of compulsory licences.

\section{Areas of Conflict in Model BIT of U.S. and India}

Both the countries maintains the cordial relationship on the issues defence cooperation, terrorism and international diplomacy. But on larger economic issues, the situation is not encouraging. In WTO (World Trade Organisation), both the countries are fighting on several issues. One expert opined that "the U.S. continues to accuse India of stalling the trade talks at WTO, which India vehemently counters. Also, India and the U.S. have been involved in a spate of trade disputes at the WTO. In 2015, India lost the case on the ban of poultry imports to the U.S. at the WTO. Currently, India and the U.S. are holding consultations at the WTO to resolve India's complaint about increased visa fees by the U.S. This comes immediately after India lost the solar panel case to the U.S. in the WTO. This, in turn, perhaps prompted the government to inform Parliament that India plans to file as many as 16 disputes against the U.S. in the WTO challenging the U.S.'s renewable energy programmes."” Further, India lost its case against australian companies and pending litigations of Vodafone on tax and others on IPR will have its impact on treaty negotiations. So, the environment surrounding discussion for Bilateral Investment Treaty is influenced by such considerations. Further, the model BIT of both countries has the following point of differences.

\section{Definition of Investment and Investor}

Under Model BIT of India, Investment is defined as "Investment" means an Enterprise in the Host State, constituted, organised and operated in compliance with the Law of the Host State and owned or controlled in good faith by an Investor: (i) in accordance with this Treaty; and (ii) that is at all times in compliance with the obligations under Articles 9, 10, 11 and 12 of Chapter III of this Treaty. ${ }^{4}$

\footnotetext{
${ }^{1}$ Details Avaialble at http://www.finmin.nic.in/bipa/bipa index.asp.

${ }^{2}$ Details Avialable at http://www.state.gov/e/eb/ifd/bit/117402.htm.

${ }^{3}$ Avaialable at $\mathrm{http}: / / \mathrm{www}$.thehindu.com/opinion/op-ed/indiaus-bilateral-investment-treaty-bit-of-a-bumpyride/article8677868.ece.

${ }^{4}$ Model BIT india, Article 1.6, Avaialble at

https://www.mygov.in/sites/default/files/master_image/Model\%20Text $\% 20$ for $\% 20$ the $\% 20$ Indian\%20Bilateral\% 20Investment\%20Treaty.pdf.
} 
So, investment definition is restricted by enterprise in the host state. The word enterprise is defined as " (i) any legal entity constituted, organised and operated in compliance with the Law of the Host State, including any company, corporation, limited liability partnership or a joint venture; and (ii) having its management and real and substantial business operations in the territory of the host State." 5

It is pertinent to mention herein that the word real and substantial business connections have been used intentionally to focus on those enterprises, which carries substantial activities. However, under the draft BIT, it is clearly defined as " an Enterprise to have, without exception, all the following elements: (i) made a substantial and long-term commitment of capital in the Host State; (ii) engaged a substantial number of employees in the territory of the Host State; (iii) assumed entrepreneurial risk; (iv) made a substantial contribution to the development of the Host State through its operations along with transfer of technological know how, where applicable; and (v) carried out all its operations in accordance with the Law of the Host State." It has been further defined that what is excluded from the definition of real and substantial connections. It says that "Real and substantial business operations" do not include: (i) objectives/strategies/arrangements, the main purpose or one of the main purposes of which is to avoid tax liabilities; (ii) the passive holding of stock, securities, land, or other property; or (iii) the ownership or leasing of real or personal property used in a trade or business."

Further, the model BIT clearly list the excluded items from the meaning of investment. It says that "Investment does not include the following assets of an Enterprise: (i) any interest in debt securities issued by a government or government- owned or controlled enterprise, or loans to a government or government-owned or controlled enterprise; (ii) any pre-operational expenditure relating to admission, establishment, acquisition or expansion of the Enterprise that is incurred before the commencement of substantial and real business operations of the Enterprise in the Host State; (iii) portfolio investments; (iv) claims to money that arises solely from commercial contracts for the sale of goods or services; (v) Goodwill, brand value, market share or similar intangible rights; (vi) claims to money that arise solely from the extension of credit in connection with any commercial transaction referred to in (v) above; (vii)an order or judgment sought or entered in any judicial, regulatory, administrative, or arbitral proceeding; (viii) any other claims to money that do not involve the kind of interests or operations set out in the definition of Investment in this Treaty." ${ }^{8}$ Further, a holding company or an investment company shall not be considered an Investment nor shall such companies be considered as protected assets of an Investment. ${ }^{9}$

Under U.S. model BIT investment is defined as "investment" means every asset that an investor owns or controls, directly or indirectly, that has the characteristics of an investment, including such characteristics as the commitment of capital or other resources, the expectation of gain or profit, or the assumption of risk. Forms that an investment may take include: ${ }^{10}$

(a) an enterprise;

(b) shares, stock, and other forms of equity participation in an enterprise;

(c) bonds, debentures, other debt instruments, and loans; ( it includes Some forms of debt, such as bonds, debentures, and long-term notes, are more likely to have the characteristics of an investment, while other forms of debt, such as claims to payment that are immediately due and result from the sale of goods or services, are less likely to have such characteristics.)

(d) futures, options, and other derivatives;

\footnotetext{
${ }^{5}$ Ibid, Art. 1.2.

${ }^{6}$ Ibid, Art. 1.2.1.

${ }^{7}$ Ibid, Art 1.2.2.

${ }^{8}$ Ibid, Art 1.7.

${ }^{9}$ lbid, Art 1.8.

${ }^{10}$ U.S. Model BIT 2012, Avaialble at

https://ustr.gov/sites/default/files/BIT\%20text\%20for\%20ACIEP\%20Meeting.pdf.
} 
(e) turnkey, construction, management, production, concession, revenue-sharing, and other similar contracts;

(f) intellectual property rights;

(g) licenses, authorizations, permits, and similar rights conferred pursuant to domestic law; (It will include Whether a particular type of license, authorization, permit, or similar instrument (including a concession, to the extent that it has the nature of such an instrument) has the characteristics of an investment depends on such factors as the nature and extent of the rights that the holder has under the law of the Party. Among the licenses, authorizations, permits, and similar instruments that do not have the characteristics of an investment are those that do not create any rights protected under domestic law. For greater certainty, the foregoing is without prejudice to whether any asset associated with the license, authorization, permit, or similar instrument has the characteristics of an investment.) ${ }^{11}$

Investor is defined under U.S model BIT as “"investor of a Party" means a Party or state enterprise thereof, or a national or an enterprise of a Party, that attempts to make, is making, or has made an investment in the territory of the other Party; provided, however, that a natural person who is a dual national shall be deemed to be exclusively a national of the State of his or her dominant and effective nationality." 12

Under Indian Model BIT, investor is defined as "investor" means a natural or juridical person of a Party, other than a branch or representative office, that has made an investment in the territory of the other Party; For the purposes of this definition, a "juridical person" means: (a) a legal entity that is constituted, organised and operated under the law of that Party and that has substantial business activities in the territory of that Party; or (b) a legal entity that is constituted, organised and operated under the laws of that Party and that is directly or indirectly owned or controlled by a natural person of that Party or by a legal entity mentioned under sub clause (a) herein. ${ }^{13}$

So, in the definition of investment and investor, the difference of ideas is most problematic. It is important as whose interest is being protected and what kinds of investments are protected. As mentioned above, U.S. model focus on asset based definition including property ( movable and immovable), Intellectual Property Rights, securities and contractual transactions. Whereas the Indian model BIT investment definition is focussed on enterprise including long-range investment and substantial business activities.

Thus in U.S. model BIT, even a small investment with minimum capital and few number of persons are protected, under Indian Definition, it will not be covered. Further, the Indian Model BIT excludes portfolio investments, government debt securities, commercial contracts, goodwill and other intangible assets of an enterprise. So, the focus on two countries on two different aspects makes it difficult to negotiate.

However, the major bone of contention is IPR related issues and portfolio investment. While U.S. wants greater protection of IPR and portfolio investment under definition of investment, India would not be willing to show flexibility by enlarging the scope of investment.

\section{Subject Matter excluded from the treaty}

As stated earlier, India lost the case before the international Tribunal against Australian companies and Vodafone dispute has impacted a lot in the drafting of this model BIT. Further, it has been influenced by increasing compulsory licensing and Intellectual Property Rights ( Hereinafter referred as IPR) . Accordingly, in model BIT following things are excluded. It says that "This Treaty shall not apply to (i) government procurement. (ii) subsidies or grants provided by a Party. (iii) services supplied in the exercise of governmental authority by the relevant body or authority of a Party. For the purposes of this Treaty, a service supplied in the exercise of governmental authority means any

\footnotetext{
11 Ibid.

${ }^{12}$ Ibid, Article 1.

13 Supra Note 4, Art 1.5.
} 
service which is supplied neither on a commercial basis nor in competition with one or more service suppliers. (iv)any taxation Measure. Where a Host State asserts as a defence that conducts alleged to be a breach of its obligations under this Treaty is a subject matter of taxation which is excluded by this Article from the scope under this Treaty, any decision of the Host State, whether before or after the commencement of arbitral proceedings, shall be non-justiciable and it shall not be open to any arbitration tribunal to review any such decision. (v) the issuance of compulsory licenses granted in relation to intellectual property rights, or to the revocation, limitation or creation of intellectual property rights, to the extent that such issuance, revocation, limitation or creation is consistent with the Law of the Host State. (vi)any commercial contract or agreement between a Party and an Investment or an Investor with respect to its Investment. Any dispute arising under such contract or agreement shall only be resolved in accordance with the dispute settlement procedure specified in such contract or agreement and if no such procedure is specified, the applicable Law of the Host State. Such disputes shall not be brought before a tribunal under Article 14 or Article 15 of this Treaty under any circumstance." 14

In U.S. model BIT, the definition of investment includes IPR, compulsory licences and authorizations, permits, and similar rights conferred pursuant to domestic law. So, it would be unlikely that U.S. will agree on Indian model of BIT.

\section{MFN and National Treatment Clause}

Modern BIT's are concluded with these two important clauses. Under MFN clause, a country agrees to accord same treatment to the foreign investors as it is giving to any third country and under National treatment clause, a country agrees to accord same treatment to the foreign investors as that of its investors. In the case of White Industries case, it was observed by the International Tribunal that "White Industries could borrow the 'effective means' provision present in the India-Kuwait BIT by relying on the MFN provision of the India-Australia BIT." 15 India had a bitter experience with this clause in this case. Accordingly, the Indian model BIT provides for national treatment only. MFN Clause is not present in model Indian BIT. ${ }^{16}$

On national Treatment, Article 4.1 says that "Each Party shall not apply to Investments, Measures that accord less favourable treatment than that it accords, in like circumstances, to domestic investments with respect to the management, conduct, operation, sale or other disposition of Investments in its territory." 17

Article 4.2 says that "A breach of Article 4.1 will only occur if the challenged Measure constitutes intentional and unlawful discrimination against the Investment on the basis of nationality." ${ }^{18}$ Further, the concept of national treatment was further restricted by mentioning that "This Article shall not apply to any Law or Measure of a Regional or local Government and Exercises of discretion, including decisions regarding whether, when and how to enforce or not enforce a Law shall not constitute a violation of this Article provided such decisions are taken in furtherance of the Law of the Host State "19 . Further, Grounds like public health, environment and safety are added in existing ground of public policy for considering non-violation of this idea. ${ }^{20}$

Under U.S. model BIT, Article 3 provides National treatment clause. It says that "Each Party shall accord to investors of the other Party treatment no less favourable than that it accords, in like circumstances, to its own investors with respect to the establishment, acquisition, expansion,

\footnotetext{
${ }^{14}$ Ibid, Art. 2.6.

${ }^{15}$ Avaailable at http://www.italaw.com/cases/documents/1170.

${ }^{16}$ Ibid.

${ }^{17}$ Ibid, Art. 4.1.

${ }^{18}$ Ibid, Art. 4.2.

${ }^{19}$ Ibid, Art . 4.3 and Art. 4.4

${ }^{20}$ Ibid, Art 4.5 .
} 
management, conduct, operation, and sale or other disposition of investments in its territory." It further says that "Each Party shall accord to covered investments treatment no less favourable than that it accords, in like circumstances, to investments in its territory of its own investors with respect to the establishment, acquisition, expansion, management, conduct, operation, and sale or other disposition of investments. 3. The treatment to be accorded by a Party under paragraphs 1 and 2 means, with respect to a regional level of government, treatment no less favourable than the treatment accorded, in like circumstances, by that regional level of government to natural persons resident in and enterprises constituted under the laws of other regional levels of government of the Party of which it forms a part, and to their respective investments. ${ }^{21}$

Article 4 of U.S. BIT provides for Most favoured nation treatment. It says that "Each Party shall accord to investors of the other Party treatment no less favourable than that it accords, in like circumstances, to investors of any non-Party with respect to the establishment, acquisition, expansion, management, conduct, operation, and sale or other disposition of investments in its territory. 2. Each Party shall accord to covered investments treatment no less favourable than that it accords, in like circumstances, to investments in its territory of investors of any non-Party with respect to the establishment, acquisition, expansion, management, conduct, operation, and sale or other disposition of investments. ${ }^{22}$

It further says that " No Party shall subject investments made by investors of the other Party to measures which constitute a violation of customary international law through: (i) Denial of justice in any judicial or administrative proceedings; or (ii) fundamental breach of due process; or (iii) targeted discrimination on manifestly unjustified grounds, such as gender, race or religious belief; or (iv)manifestly abusive treatment, such as coercion, duress and harassment. Each Party shall accord in its territory to investments of the other Party and to investors with respect to their investments full protection and security. For greater certainty, "full protection and security" only refers to a Party's obligations relating to physical security of investors and to investments made by the investors of the other Party and not to any other obligation whatsoever."23

So, the U.S. model BIT contains a Most Favoured Nation (MFN) provision and investor friendly National Treatment Clause, which is also present in most of the standard BIT ,but Indian Model does not provide MFN status. Even national treatment clause is also very restrictive. U.S will not like to accept the same concept in the treaty .Indian multinational presence is not much in U.S. so for India it is difficult to initiate the process of giving MFN status to anyone. However, India has entered into BIT with U.K . Containing MFN clause. So it is expected that India will be agreed for MFN Clause.

\section{Expropriation}

Expropriating is the most important concept in BIT . The investment made by the investor should be immune from any sort of expropriation.

Indian model BIT provides that "Neither Party may nationalize or expropriate an investment of an investor (hereinafter "expropriate") of the other Party either directly or through measures having an effect equivalent to expropriation, except for reasons of public purpose, in accordance with the due process of law and on payment of adequate compensation. ${ }^{24}$

Further, Measures or series of measures must have affected to following situations :

(i) permanent and complete or near complete deprivation of the value of Investment; and

(ii) permanent and complete or near complete deprivation of the Investor's right to management and control over the Investment

\footnotetext{
${ }^{21}$ Supra Note 10 , Article 3 .

${ }^{22}$ Ibid, Article 4.

${ }^{23}$ Ibid.

${ }^{24}$ Supra Note 4, Art. 5.1.
} 
(iii) an appropriation of the Investment by the Host State which results in transfer of the complete or near complete value of the Investment to that Party or to an agency or instrumentality of the Party or a third party. ${ }^{25}$

Further, action taken by a Party in its commercial capacity shall not constitute expropriation and nondiscriminatory regulatory actions by a Party that are designed and applied to protect legitimate public welfare objectives such as public health, safety, and the environment shall not constitute expropriation. ${ }^{26}$

Under U.S. model BIT, Art 6 provides that “ Neither Party may expropriate or nationalize a covered investment either directly or indirectly through measures equivalent to expropriation or nationalization ("expropriation"), except: (a) for a public purpose; (b) in a non-discriminatory manner; (c) on payment of prompt, adequate, and effective compensation (d) in accordance with due process of law and Minimum Standard of Treatment." ${ }^{27}$ it further provides that " the compensation referred to in paragraph (c) shall: (a) be paid without delay; (b) be equivalent to the fair market value of the expropriated investment immediately before the expropriation took place ("the date of expropriation"); (c) not reflect any change in value occurring because the intended expropriation had become known earlier; and (d) be fully realizable and freely transferable. 3. If the fair market value is denominated in a freely usable currency, the compensation referred to in paragraph 1(c) shall be no less than the fair market value on the date of expropriation, plus interest at a commercially reasonable rate for that currency, accrued from the date of expropriation until the date of payment. 4. If the fair market value is denominated in a currency that is not freely usable, the compensation referred to in paragraph 1(c) - converted into the currency of payment at the market rate of exchange prevailing on the date of payment - shall be no less than: (a) the fair market value on the date of expropriation, converted into a freely usable currency at the market rate of exchange prevailing on that date, plus (b) interest, at a commercially reasonable rate for that freely usable currency, accrued from the date of expropriation until the date of payment." 28

Further, Art 21 provides that "Article 6 [Expropriation] shall apply to all taxation measures, except that a claimant that asserts that a taxation measure involves an expropriation may submit a claim to arbitration under Section B only if: (a) the claimant has first referred to the competent tax authorities 21 of both Parties in writing the issue of whether that taxation measure involves an expropriation; and (b) within 180 days after the date of such referral, the competent tax authorities of both Parties fail to agree that the taxation measure is not an expropriation." 29

So, taxation related dispute is not covered under Indian BIT but covered under U.S. BIT . The Indian model completely excludes taxation from the purview of the BIT. India has already faced problems in the cases Vodafone and Cairn Energy, where these two companies have brought claims against India for imposing taxes retrospectively. However, in the U.S. model, foreign investors can assert claims that taxation measures, such as confiscatory taxation, involve an expropriation of foreign investment.So, India would not like to enter into BIT which includes tax disputes as part of investment and U.S would not accept the exclusion of tax from the investment. Both the countries are expected to be flexible to make BIT a reality.

\section{Dispute Resolution Mechanism}

Dispute resolution mechanism is most important part of BIT as local courts are not preferred by an international investor. It is believed that local courts and tribunals are the extensions of country

\footnotetext{
${ }^{25}$ Ibid, 5.2 .

${ }^{26} \mathrm{Ibid}$, Art 5.3 and 5.4.

${ }^{27}$ Supra Note 10, Art 6.

28 Ibid.

${ }^{29}$ Ibid, Art. 21.
} 
sovereign power so they can't not work independently. Further, they are biased with the investors of local country and it does not has the expertise to solve problems of international investment law. Accordingly, most BIT supports for adjudication of disputes by international tribunal and law of third country law or international law .

Indian BIT is very restrictive with respect to the jurisdiction of an international tribunal in international investment disputes. Indian BIT provides for establishment of a tribunal under this chapter to decide such disputes arising out of an alleged breach of an obligation of a Party. But the Tribunal constituted under this Chapter shall not have the jurisdiction to (i) review the merits of a decision made by a judicial authority of the Parties; or (ii) accept jurisdiction over any claim that is or has been the subject of an arbitration under Art $15 .{ }^{30}$

Art 14.3 provides for Exhaustion of Local Remedies, Notice and Consultation process before the filing of the claim to the international tribunal . It says that " (i) The Investor or Investment must first submit its claim before the relevant domestic courts or administrative bodies of the Host State for the purpose of pursuing domestic remedies. Such claim must be submitted within one (1) year from the date on which the Investor or Investment first acquired, or should have first acquired, knowledge of the Measure in question and knowledge that the Investment, or the Investor with respect to its Investment, had incurred loss or damage as a result. (ii) If a. after exhausting all judicial and administrative remedies relating to the Measure underlying the claim, no resolution has been reached satisfactory to the Investor or Investment; orb. having diligently pursued domestic remedies, the Investor or Investment has determined and can establish that continued pursuit of domestic relief would be futile because (1) there are no reasonably available domestic legal remedies capable of providing any relief for the dispute concerning the underlying Measure, or (2) that the process for obtaining legal relief provides no reasonable possibility of such relief in a reasonable period of time. ${ }^{31}$

So, Indian BIT now makes it mandatory to exhaust local remedy before filing the claims.

Whereas U.S BIT Article 23 provides "In the event of an investment dispute, the claimant, and the respondent should initially seek to resolve the dispute through consultation and negotiation, which may include the use of non-binding, third-party procedures. " 32

However under Article 24, In the event that a disputing party considers that an investment dispute cannot be settled by consultation and negotiation: (a) the claimant, on its own behalf, may submit to arbitration under this Section a claim (i) that the respondent has breached (A) an obligation under Articles 3 through 10, (B) an investment authorization, or (C) an investment agreement; and (ii) that the claimant has incurred loss or damage by reason of, or arising out of, that breach; and (b) the claimant, on behalf of an enterprise of the respondent that is a juridical person that the claimant owns or controls directly or indirectly, may submit to arbitration under this Section a claim (i) that the respondent has breached - 27 - (A) an obligation under Articles 3 through 10, (B) an investment authorization, or $(\mathrm{C})$ an investment agreement; and (ii) that the enterprise has incurred loss or damage by reason of, or arising out of, that breach, provided that a claimant may submit pursuant to subparagraph (a)(i)(C) or (b)(i)(C) a claim for breach of an investment agreement only if the subject matter of the claim and the claimed damages directly relate to the covered investment that was established or acquired, or sought to be established or acquired, in reliance on the relevant investment agreement." ${ }^{33}$ However, at least 90 days before submitting any claim to arbitration under this Section, a claimant shall deliver to the respondent a written notice of its intention to submit the claim to arbitration ("notice of intent"). The notice shall specify: (a) the name and address of the claimant and, where a claim is submitted on behalf of an enterprise, the name, address, and place of incorporation of the enterprise; (b) for each claim, the provision of this Treaty, investment authorization, or investment agreement alleged to have been breached and any other relevant provisions; (c) the legal and factual basis for each claim; and (d) the relief sought and the approximate amount of damages claimed. 3 .

\footnotetext{
${ }^{30}$ Ibid, Art. 14.2.

31 lbid Art 14.3.

${ }^{32}$ Supra Note 10 , Art 23

33 Ibid, Art 23.
} 
Provided that six months have elapsed since the events giving rise to the claim, a claimant may submit a claim referred to in paragraph 1: (a) under the ICSID Convention and the ICSID Rules of Procedure for Arbitration Proceedings, provided that both the respondent and the non-disputing Party are parties to the ICSID Convention; (b) under the ICSID Additional Facility Rules, provided that either the respondent or the non-disputing Party is a party to the ICSID Convention; (c) under the UNCITRAL Arbitration Rules; or (d) if the claimant and respondent agree, to any other arbitration institution or under any other arbitration rules.

So, the dispute resolution mechanism also varies in the model BIT of two countries. In India, without exhausting the local remedies, another party cannot proceed for international arbitration. However, in U.S a party can directly approach the international tribunal after the expiry of some time. Indian Model BIT lays emphasis on adjudication by local courts. U.S. is aware of the ground reality of pending litigations before Indian courts. So, U.S. would not be agreeing to this clause. At the same time, Indian would not want international tribunals to take charge before exhausting the local remedies. Both the parties are again required to take a flexible approach on this. However, India may propose of special courts or tribunals to adjudicate the disputes between India and U.S. recently brought Commercial Courts Act, 2015, would further help in speedy disposal of commercial disputes.

\section{Conclusion}

So, the differences between the two countries can be through the process of negotiations. U.S. needs to tilt towards Indian concern with respect to IPR related issues, compulsory licensing and portfolio investments, whereas, India has to grant MFN status as that of U.K. and remain flexible towards substantial investment. India can define investment in terms of capital or turnover rather than focusing entirely on substantial business activities covering manpower and enterprise-based approach. On the issues of Compulsory licensing, MFN Status, Taxation, and Dispute resolution mechanism, the two countries will have to find the common ground on mutual understanding, benefit and long term goals. It will also depend on what India nd U.S. are getting from each other. Both the parties have to search for the mutually acceptable pathway . 